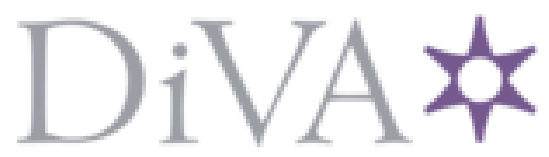

http://www.diva-portal.org

\title{
Postprint
}

This is the accepted version of a paper published in Studia Neophilologica. This paper has been peerreviewed but does not include the final publisher proof-corrections or journal pagination.

Citation for the original published paper (version of record):

Watson, C. (2014)

The Treatment of Graphic Variation in Slavic and Latin Editorial Philology.

Studia Neophilologica, 86(supp. 1): 187-200

http://dx.doi.org/10.1080/00393274.2013.853375

Access to the published version may require subscription.

N.B. When citing this work, cite the original published paper.

Permanent link to this version:

http://urn.kb.se/resolve?urn=urn:nbn:se:uu:diva-2 14062 


\section{The Treatment of Graphic Variation in Slavic and Latin Editorial Philology Christine Watson}

This article compares some aspects of editorial principles in Latin and Slavic (Cyrillic) philology. The emphasis is on matters of graphic variation and orthography. In Latin philology, the main determining factor when choosing editorial principles is whether the text is classical or medieval. Slavic tradition, on the other hand, takes into consideration not only the age of the manuscript but also the intended readership of the edition: editions aimed at linguists follow other principles than those aimed at e.g. scholars of literature or history. Two aspects that are rarely discussed in connection with Latin texts, but that are important in Slavic editorial tradition, are the choice of font and the question of which letters or letter variants are to be rendered in editions. The different principles are illustrated, and some possible reasons for the differences between the Latin and the Slavic traditions are suggested.

\section{Introduction}

When I began editing a $17^{\text {th }}$-century Russian manuscript as a part of my dissertation work (cf. Watson 2012), I faced a number of decisions regarding editorial principles. Besides using other editions of Russian texts for guidance, I turned to editions of Latin texts for comparison. I soon realized, however, that although some questions concern Latin and Slavic scholars alike - such as whether to prepare a diplomatic or a critical edition - there are some major differences between the two traditions.

In this article, I will compare some aspects of editorial principles in Latin and Slavic philology. By the latter I mean editions of texts written in the Cyrillic alphabet, and I will concentrate on the Russian tradition, i.e. editions made in Russia of Old Church Slavonic and Church Slavonic texts, or editions of Old Russian texts, although other countries that use the Cyrillic alphabet (e.g. Bulgaria) seem to belong to the same tradition. The emphasis will be on graphic and orthographic matters.

In this article, I will use the term 'orthographic' to refer to the choice between different graphemes, and 'graphic' to refer to the choice of fonts, variants of a single grapheme and similar matters. It must, however, be kept in mind that this is not always a clear-cut distinction, which will be seen in Section 6 (cf. also Pennington 1980: 190). The use of scribal abbreviations and punctuation is somewhat of a borderland between the two, but will here be assigned to orthography.

Since Slavic languages are not the usual subject matter of this journal, the circumstances surrounding Slavic editions will be described in more detail than Latin editions, which may be more familiar to the readers. I will limit the discussion on Western editorial tradition to classical and medieval Latin texts, leaving aside the questions connected with Western vernacular texts. The treatment of vernacular texts may in some cases differ substantially from what is the norm for Latin texts, but nevertheless, one can speak of a general Western tradition of textual criticism, as opposed to the Russian-Ukrainian 'textology' (tekstologija). The differences between these 
approaches have been discussed by Ostrowski (2003: XLV-LVI), but are beyond the scope of this article.

Because Latin and Slavic tradition differ as to the amount of attention they devote to graphic and orthographic matters, the literature available is also different. Although the debate on editorial technique is active in the Classical tradition, I have found few works that discuss Latin graphics and orthography, and those are mostly connected with editions of medieval Latin. Interestingly, one of the most thorough discussions of these matters that I have found is based on a lecture aimed not at Latinists, but at scholars of medieval Scandinavian philology (Öberg 1992).

The Slavic part is mainly based on two sources, the best known of which is D. S. Lichačëv's Tekstologija (2001; $1^{\text {st }}$ ed. 1962), one of the cornerstones in Russian editorial philology. I will also refer to the booklet Pravila lingvističeskogo izdanija pamjatnikov drevnerusskoj pis'mennosti (1961), which was the result of an effort to standardize the principles for linguistic editions of Slavic texts, although it does not seem to have had any great impact and is not widely used by editors.

\section{The Cyrillic alphabet and Cyrillic paleography}

The Cyrillic alphabet was one of two alphabets (the other, probably older, was the Glagolitic alphabet) devised for writing Old Church Slavonic (OCS), a written language based on South Slavic dialects spoken in Macedonia in the $9^{\text {th }}$ century (cf. Nandriş 1965: 1-2). OCS later developed into various local redactions of Church Slavonic, which are still used in the Orthodox church. The alphabet was patterned on (post-classical) Greek, and for this reason it had two letters that represented the phoneme /i/, just as Greek had eta and iota, and two letters for /o/, corresponding to omicron and omega, and /u/ was rendered by a digraph, as it was in Greek.

In the course of time, the Slavic language family split up into different branches, which underwent changes of different kinds. Of most relevance to this article are the sound changes that affected the relation between letters and phonemes. As already mentioned, I will concentrate on Russian, which belongs to the East Slavic branch.

Some of these sound changes, such as the loss of nasality, resulted in the merging of two originally different phonemes. This meant that the number of phonemes was reduced, but the share of phonemes that could be represented by two different letters grew larger.

Table 1 shows what is generally considered to be the original setup of the Cyrillic alphabet, although the order of the letters is partly uncertain. I have numbered the letters to facilitate reference, but these are not the actual numerical values of the letters. The table is based on Nandriş (1965) and Leskien (1886).

Table 1. The Cyrillic alphabet as found in OCS

\begin{tabular}{|l|l|l|l|}
\hline & Letter & Transcription & Comments \\
\hline 1 & a & a & \\
\hline
\end{tabular}




\begin{tabular}{|c|c|c|c|}
\hline 2 & B & $\mathrm{b}$ & \\
\hline 3 & в & $\mathrm{v}$ & \\
\hline 4 & $\Gamma$ & $\mathrm{g}$ & \\
\hline 5 & A & d & \\
\hline 6 & $\mathfrak{E}$ & e & Eventually merged with $\mathrm{t}$ (33) in most Russian dialects. \\
\hline 7 & ж & $\check{z}$ & \\
\hline 8 & $\mathrm{~s}$ & $\mathrm{dz}$ & Eventually merged with 3 (9) in Russian. \\
\hline 9 & 3 & $\mathrm{z}$ & Eventually merged with $s(8)$ in Russian. \\
\hline 10 & 1 & $\mathrm{i}$ & Represented the same phoneme as $\mathrm{u}(11)$ in OCS and Russian. \\
\hline 11 & n & i & Represented the same phoneme as I (10) in OCS and Russian. \\
\hline 12 & $\kappa$ & $\mathrm{k}$ & \\
\hline 13 & $\lambda$ & l & \\
\hline 14 & M & $\mathrm{m}$ & \\
\hline 15 & $\mathrm{~N}$ & $\mathrm{n}$ & \\
\hline 16 & 0 & 0 & Represented the same phoneme as w (25) in OCS and Russian. \\
\hline 17 & $\Pi$ & $\mathrm{p}$ & \\
\hline 18 & $p$ & $\mathrm{r}$ & \\
\hline 19 & c & $\mathrm{s}$ & \\
\hline 20 & T & $\mathrm{t}$ & \\
\hline 21 & or & $\mathrm{u}$ & Eventually merged with $\pi$ (38) in Russian. \\
\hline 22 & $\phi$ & $\mathrm{f}$ & Eventually merged with o (23) in Russian. \\
\hline 23 & 8 & th & Eventually merged with $\phi(22)$ in Russian. \\
\hline 24 & $x$ & ch & \\
\hline 25 & $w$ & 0 & Represented the same phoneme as o (16) in OCS and Russian. \\
\hline 26 & $\psi$ & št & \\
\hline 27 & 4 & ts & \\
\hline 28 & $\varphi$ & $\check{\mathrm{c}}$ & \\
\hline 29 & ш & $\check{\mathrm{s}}$ & \\
\hline 30 & $\mathrm{z}$ & $\breve{\mathrm{u}}$ or $\mathrm{b}$ & $\begin{array}{l}\text { Originally a reduced vowel, the exact pronunciation of which in } \\
\text { OCS is uncertain. }\end{array}$ \\
\hline 31 & b & ĭ or b & $\begin{array}{l}\text { Originally a reduced vowel, the exact pronunciation of which in } \\
\text { OCS is uncertain. }\end{array}$ \\
\hline 32 & $\mathrm{Zl}$ & $\mathrm{y}$ & \\
\hline 33 & t & ě & Eventually merged with $\mathfrak{\varepsilon}(6)$ in most Russian dialects. \\
\hline 34 & la & ja & Eventually merged with $\mathrm{A}$ (37) in Russian. \\
\hline 35 & If & je & \\
\hline 36 & to & ju & \\
\hline 37 & A & ę (nasal e) & Lost nasality early and merged with ra (34) in Russian. \\
\hline 38 & $\pi$ & $\mathrm{Q}$ (nasal o) & Lost nasality early and merged with or (21) in Russian. \\
\hline 39 & IA & ję & \\
\hline 40 & 迹 & jo & \\
\hline
\end{tabular}




\begin{tabular}{|l|l|l|l|}
\hline 41 & $\grave{3}$ & ks & \\
\hline 42 & $\psi$ & ps & \\
\hline 43 & v & i, v & \\
\hline
\end{tabular}

As can be seen from the table, there were seven pairs of letters whose pronunciation coincided with each other either in OCS or, later, in Russian. They were treated in various ways, depending on the letter pair and time period. In some cases, the norm prescribed that the two letters be used in different positions: for instance, one was used word-initially and the other in all other positions, or they were used to resolve homonymy between words or grammatical forms. Some letter pairs could be used in free variation and serve decorative purposes, at least in certain kinds of texts or in texts from certain time periods (cf. Pennington 1980: 190-196).

There are three main categories of early Cyrillic handwriting: ustav, poluustav and skoropis' (sometimes translated as uncials, semi-uncials and cursive). Ustav was an upright majuscule script that was used in the $11^{\text {th }}-13^{\text {th }}$ centuries. It is often characterized as being even and formal; ligatures were scarce, and the relation of the width and height of the letters was often 1:1 (Čerepnin 1956: 150-153). Poluustav developed in the $14^{\text {th }}$ century, and it is distinguished from ustav mainly by being less formal, more slanted and containing more ligatures and abbreviations (Čerepnin 1956: 239-240). As early as the $15^{\text {th }}$ century, these signs of hasty writing became even more pronounced in skoropis', which prevailed during the following centuries. Another typical feature of skoropis' was that most letters had several variants from which the scribe could choose freely, and that could co-occur in the same text or even in the same word (Čerepnin 1956: 246-248). In some cases the letter variants could serve to make certain words distinct and easily recognizable (Pennington 1980: 190).

Figure 1 shows a page from the Ostromir Gospel (1056-1057), written in ustav. Figure 2 shows a page from the Russian translation of Maciej Stryjkowski’s Kronika polska, in a manuscript from the early 1680s, written in skoropis'. 


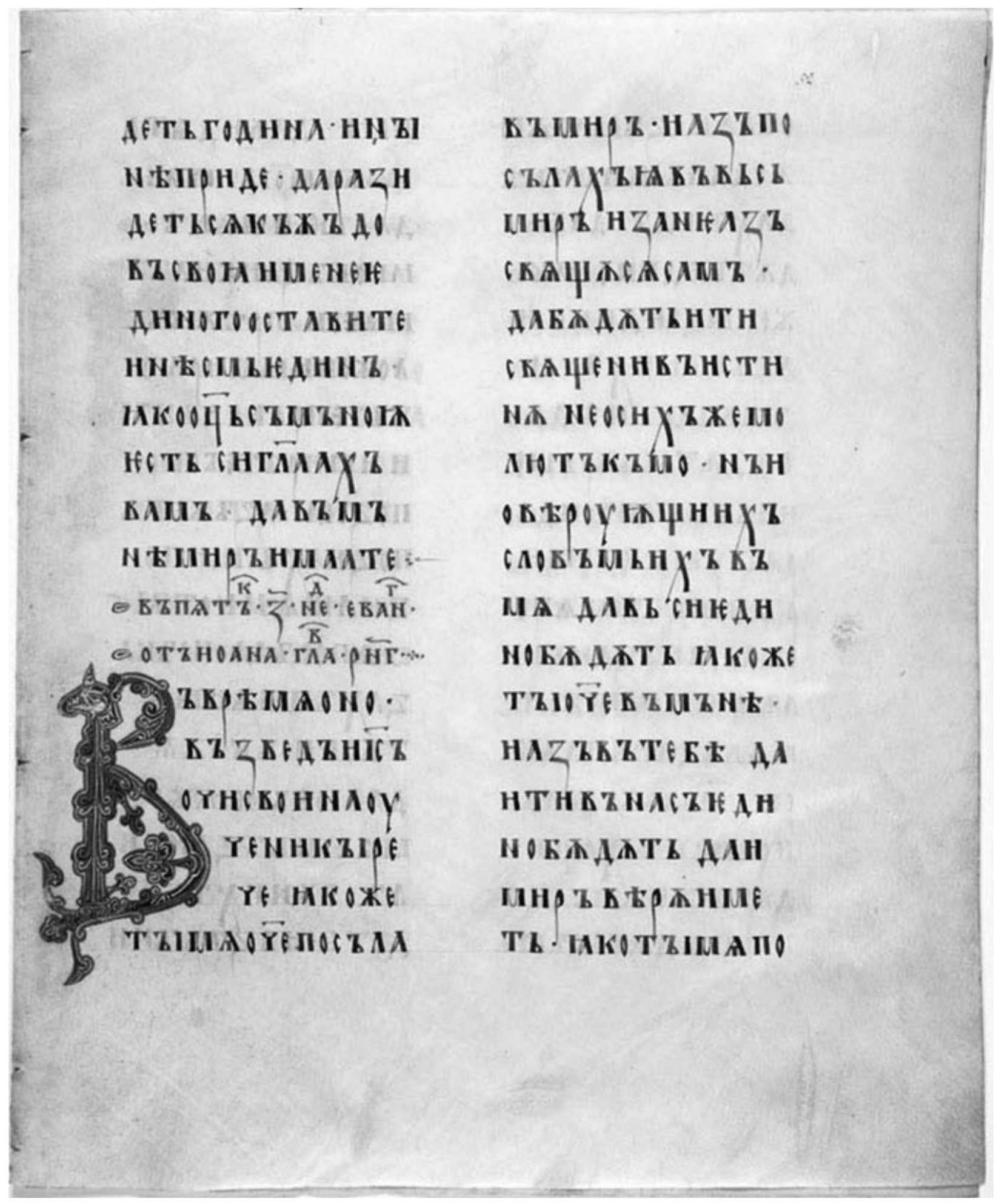

Figure 1. Ostromir Gospel. National Library of Russia, Manuscript Department, F.p.I.5, fol. 25r. Digital image taken from the web site http://www.nlr.ru/exib/Gospel/ostr/ill.html, published with kind permission from the National Library of Russia. 


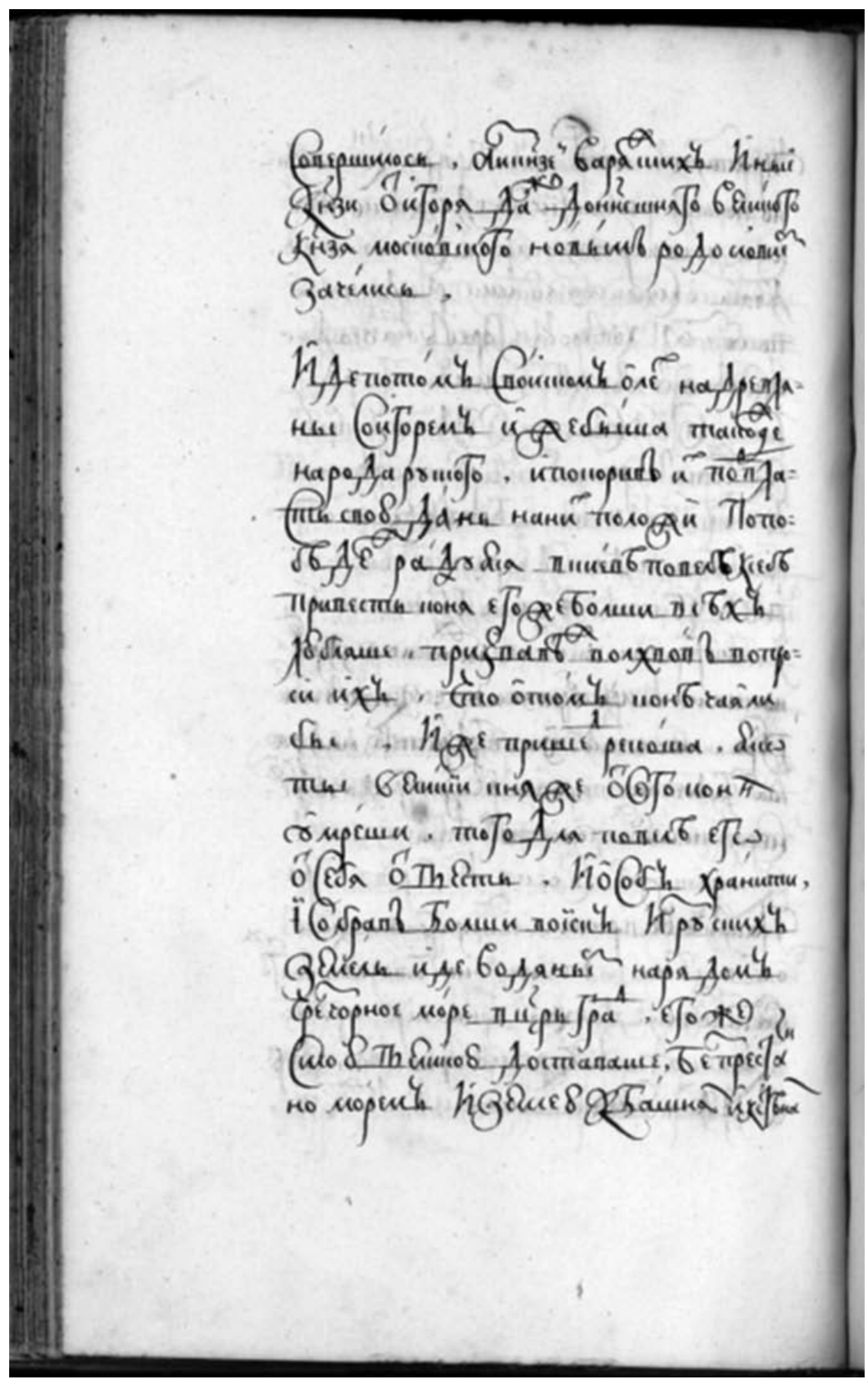

Figure 2. Translation of Maciej Stryjkowski's Kronika polska, Uppsala University Library, Manuscript Department, Slav 26, fol. 198v. 


\section{Two main distinctions}

The age of the manuscript and the age of the text are important in both Latin and Slavic tradition when deciding on editorial principles. For Latin, the main divide runs between classical and medieval texts. Classical texts are often only known in later copies, and the editor's aim is usually to reconstruct the text as the author intended it, not to reflect the characteristics of the medieval tradition. When editing medieval texts from medieval manuscripts, however, other rules apply, and more attention is paid to the historically attested text as found in manuscripts (cf. Tarrant 1995: 96).

D. S. Lichačëv saw a chronological border in Slavic manuscripts as well. In his opinion, texts written before the end of the $14^{\text {th }}$ century should be treated differently than texts written after that date, and more detail should be given in editions. His main argument is the fact that an orthographic reform took place around this time, bringing South Slavic influence into the written language in Russia. In most cases, he did not consider it desirable to render this borrowed orthography (Lichačëv 2001: 498-499; 503-504).

A further distinction made in Slavic tradition is the intended readership of the edition. Lichačëv made a distinction between editions aimed at linguists and editions aimed at scholars of literature and history. In his opinion, it is not only a matter of linguists demanding more detail in the editions they work with, but of the different disciplines choosing their main manuscripts and variant readings by different criteria. He also claimed that linguists are often satisfied with editions based on a single, early, well-preserved copy of a text, whereas it is more important for literary scholars and historians to use many manuscripts to study the history of the text (Lichačëv 2001: 470-474, 483). I must add that I do not agree with him on this point, and that it can be highly relevant for linguists to see e.g. which linguistic features vary between manuscripts and which do not, or the nature of the mistakes made by the scribes, which may reveal facts about their pronunciation, origin and so on.

\section{Orthography}

The two main distinctions discussed above influence further decisions on orthography. In Latin as well as Slavic tradition, there are discussions on how to treat orthographic variation. As explained in the introduction, in this article punctuation and the expansion of abbreviations are considered matters of orthography, and will therefore be dealt with here.

\subsection{Latin}

In editions of classical Latin texts, most of which are known only in medieval manuscripts, the results of medieval practice are usually not seen as relevant. Instead, the orthography of the text is adapted to classical norms in order to reflect the intentions of the author, although there are examples of editions where orthography adheres to the oldest manuscripts. Capital letters are usually introduced according to modern usage. Punctuation is also usually modernized, although 
the results of this may of course vary depending on the editor's origin and preferences (Öberg 1992: 69; Tarrant 1995: 97).

There is less agreement on how to treat orthography in medieval Latin texts. Some editors adapt them also to classical norms (Öberg 1992: 81), although other scholars protest against this procedure and argue that introducing classical spelling in the editions of medieval works is just as anachronistic as publishing late copies of classical authors with medieval spelling (Huygens 2000: 32). Other possible ways of editing medieval texts are to follow one manuscript faithfully or to introduce a normalized medieval orthography. Punctuation in editions of medieval texts is often normalized, just as in editions of classical texts, since most editors consider it to be inconsistently placed and of no interest to readers (Öberg 1992: 81; Gejrot 1995: 6).

An example of an editorial project and the principles it applies to medieval orthography is the edition of the sermons of the Vadstena brothers from 1385-1515. Here, the orthography of the manuscripts is followed closely, with the exception that $i$ and $j$, which are difficult to tell apart, are both rendered by $i$, and that $v$ is used initially and $u$ in other positions, since this is the most common distribution in the texts and this principle is followed in other projects.

Abbreviations are here expanded according to medieval spelling, without italicizing the result of the expansion (Gejrot 1995: 6-7).

\subsection{Slavic}

In editions of texts written before the end of the $14^{\text {th }}$ century, Lichačëv proposed rendering more orthographic detail, marking expanded abbreviations and marking superscript letters brought into the line. In editions of texts written from the $15^{\text {th }}$ century onwards, he did not consider it necessary to mark expanded abbreviations and superscript letters (Lichačëv 2001: 503-504). Like all his recommendations, this applies to editions aimed at literary scholars or historians.

A linguistic edition, according to the authors of the above-mentioned Russian booklet, should enable scholars not only to read and understand the text, but also to draw conclusions on each scribe's system of writing: his orthography and choice of graphemes. Therefore, they recommended paying great attention to the orthography of the manuscripts (Pravila 1961: 8).

They suggested that superscript letters either be printed above the line, approximately in the position they occupy in the manuscript (in editions of early manuscripts), or in the line, but in italics (in editions of later manuscripts). They did not approve of the expansion of abbreviated words; this applies to both early and late manuscripts. Diacritical marks should be rendered in the edition, although in late manuscripts, some of them may be omitted (Pravila 1961: 45-47).

Although less detail is usually observed in editions of late texts, there are examples of editions of $17^{\text {th }}$-century texts that stay very close to the manuscripts. One is Anne Pennington's (1980) diplomatic edition of a text from 1666-1667, preserved in only one manuscript. There, abbreviations are not expanded, but superscript letters are printed in the line in italics. Pennington did not render the diacritical marks that often accompanied superscript letters and abbreviations, which was pointed out as a drawback in one review of her book (Uspenskij \& Živov 1983: 174-175). 


\section{Choice of font}

The choice of font is rarely an issue when editing Latin texts, other than for aesthetic reasons. Although there are plenty of fonts based on the uncial, half-uncial, Carolingian minuscule and Gothic script, which makes it entirely possible to publish Latin manuscripts in a font that imitates the handwritten script, this is not usually done.

One exception is the Teubner edition of Cicero's De re publica (Ziegler 1969), which is preserved as the $4^{\text {th }}$-century underlying text of a palimpsest (Vatican Library, Vat. Lat. 5757). The main text of the edition is printed in a regular Roman typeface, but where emendations have been made, the original manuscript readings are printed in the critical apparatus in an uncial script.

In Slavic (Cyrillic) tradition, however, the choice of font is a point of discussion. There are two main categories of typefaces to choose from: Church Slavonic ones, called kirillica, or the more modern 'civil script', graždanskij šrift, which was introduced by Peter I in the early $18^{\text {th }}$ century (cf. Matthews 1960: 81). Church Slavonic script is usually used to render material written in ustav or poluustav, and modern fonts for texts written in skoropis'. This is the recommendation in the instructions for linguistic editions (Pravila 1961: 43-44). Lichačëv, however, considers it superfluous to use Church Slavonic script for literary editions, even of early texts, since it is not so similar to the handwritings it is supposed to represent anyway (Lichačëv 2001: 503).

Figure 3 shows the Church Slavonic font BukyVede and the font RomanCyrillic Std, based on the civil script and with a modern Russian appearance, but containing many of the older letters. Letters no longer in use in modern Russian are put in parentheses.

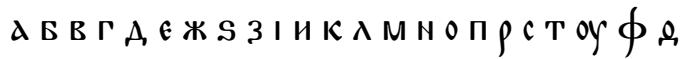

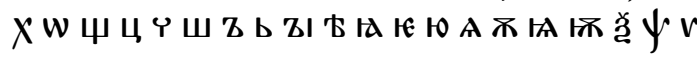

а б в г д е ж (s) з (i) и к л м н о п р с т у ф (ө) х

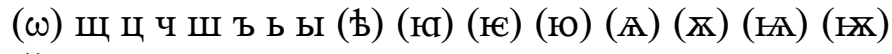
$(\xi)(\Psi)(\mathrm{v})$

Figure 3. The Church Slavonic font BukyVede and the font RomanCyrillic Std.

When comparing these font samples with the manuscript pages depicted in Figures 1 and 2, it becomes apparent that the Church Slavonic font is based on handwritten ustav, whereas the font based on the civil script is not very similar to handwritten skoropis', which indeed is so complicated and varies so much among scribes that it would be difficult to base a font on it.

\section{What is a letter?}

The question of which letters are to be rendered in an edition is also only occasionally discussed in connection with Latin. There are editions of medieval Latin texts where graphic peculiarities have been rendered in editions, such as the long s, i.e. $\int$ (Öberg 1992: 81, 84).

However, this issue is far from resolved in Slavic editions. Again, it depends in part on the age of the manuscript. Even though Lichačëv does not consider it necessary to use Church Slavonic type, he recommends keeping the letters $\theta, \hbar, F, F, A, \pi$ when editing early texts, 
written before the end of the $14^{\text {th }}$ century, although he considers the letter $i$ and the digraph oy to be unnecessary. In editions of later texts he deems it unnecessary to keep other older letters than $b$ (Lichačëv 2001: 503-504). Both $f a$ and $A$ are in that case replaced by $\boldsymbol{A}$, which is a development of $A$.

The authors of the Russian instructions for linguists recommend distinguishing between different letters in the edition, even when they represent the same phoneme, but state that the choice regarding graphic variants of one and the same letter must be made anew for each edition (Pravila 1961: 44-45). As mentioned above, skoropis' displayed a great array of letter forms, which were in free variation. The choice between these forms does not carry any phonetic, morphological, syntactic or semantic information and is therefore usually not analyzed by linguists (Pravila 1961: 11). Furthermore, the variants are not clearly defined, and intermediate forms exist.

In Figure 4, which shows an enlarged section of Figure 2, I have circled four different variants of the letter $b$, all of them common in skoropis', although not all scribal hands use all variants. Most editors would agree that this graphic variation does not need to be rendered in an edition, and that if such an attempt were made, it would obstruct reading. One may assume that any scholar for whom this variation is of interest would not be content with an edition, but would still have to turn to the manuscript itself.

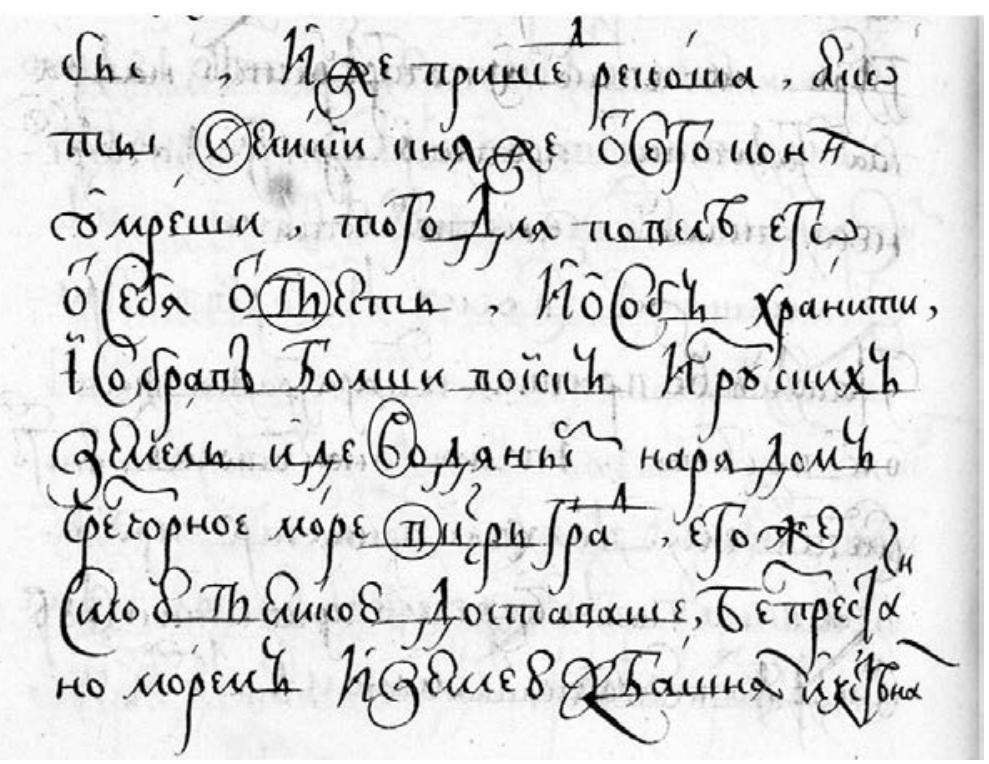

Figure 4. Translation of Maciej Stryjkowski's Kronika polska, Uppsala University Library, Manuscript Department, Slav 26, fol. 198v. Variants of the letter 8.

The question of whether we are dealing with independent letters or graphic variants of the same letter is by no means easy to decide. This is connected to what was mentioned above about the existence of letters that were pronounced alike. For instance, it has been suggested that editions intended for linguists should distinguish between the letters $h, i$ and $\ddot{i}$ (no. [10] and [11] in Table 1 above) (Pravila 1961: 44). However, most scholars treat $i$ and $\ddot{i}$ as variants of the same 
letter, whereas, as seen in the table, $u$ was distinct from them. Ever since the Cyrillic alphabet was devised, $и$ and $i / i$ had separate names and numerical values. Even editions that are usually praised for their great attention to graphic details choose either $i$ or $\ddot{i}$ to represent both (cf. Pennington 1980: 192).

One would be tempted to argue that letters that were perceived as separate at the time when the manuscript was written should also be separated in editions, but that there would be no need to distinguish what contemporaries saw as mere variants. However, at the time, the alphabet was not seen as a closed, constant system, but as an open system that allowed variation (Šustova 2011: 113-114, 134). This is shown by Ju. Ė. Šustova, who has compared numerous versions of the Cyrillic alphabet as found in primers from the $16^{\text {th }}$ and $17^{\text {th }}$ centuries, printed in Slavic countries as well as in Western Europe, and found considerable variation in the letters included and their order (Šustova 2011). In one Cyrillic primer ${ }^{1}$, printed in Tübingen in 1561, the alphabet is printed three times, each time with a slightly different set of characters. For instance, the first two alphabet rows have the letter $\mathscr{\delta}$ (a ligature of the digraph oy, no. [21]), whereas the third has both $\boldsymbol{\delta}$ and oy. All three distinguish between $\boldsymbol{o}$ and $w$ (no. [16] and [25]), but in the first and third we also find $w$, which is the letter $w$ with a superscript $\boldsymbol{r}$ (Truber 1959; Šustova 2011: 112-116, 139). In a primer printed in Moscow in 1667, there are two variants of the letter o, occupying

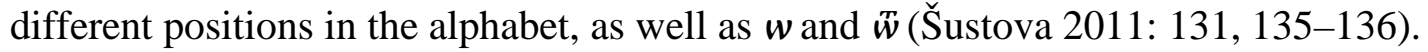

Besides primers, scrolls containing $17^{\text {th }}$-century skoropis' alphabets are also informative. They were intended to serve as models when learning this script and display its abundance of letter variants (Čerepnin 1956: 30-32). One such scroll is depicted by Čerepnin (1956, inserted between pp. 32 and 33). There, the letters of the Cyrillic alphabet are written repeatedly, either alone or in syllable combinations, with one or two rows dedicated to each letter. It reveals, for instance, that $s$ and 3 (no. [8] and [9]) were written on separate lines, indicating that the scribe saw them as separate letters. However, both the row between $H$ and $\Pi$, where $o$ (no. [16]) should be, and the row below $x$ are filled with samples of the letter $\omega(25)$, with only a few examples of $o$ towards the end of one row. As may be expected, $F a$ and $A$ ([34] and [37]) share a row, but the fact that $щ$ and $w$ ([26] and [29]) do is more unexpected, since they are still separate letters in modern Russian. At the time, however, some scribes used the two interchangeably (Uspenskij \& Živov 1983: 175-176), which stresses the point that relying only on the opinions of the scribes when determining what is a letter and what is a graphic variant is not quite enough.

\section{Cyrillic edition samples}

The difference between the possible kinds of Cyrillic editions can be seen by comparing two editions of one of the best-known works of Russian literature, the Primary Chronicle, or Povest' vremennych let. This chronicle is estimated to have been compiled around 1116, but the oldest

\footnotetext{
${ }^{1}$ This primer is defined by Šustova (2011: 112) as Croatian, although its author, Primož Trubar (Primus Truber), is usually known as the father of the Slovenian language (cf. Truber 1959).
} 
extant manuscript, the Laurentian Codex (National Library of Russia, Manuscript Department, F.p.IV.2), is from 1377 (Ostrowski 2003: XVII-XVIII).

D. S. Lichačëv prepared a critical edition, based on the Laurentian Codex but with readings from four other manuscripts, according to his principles for literary editions. This edition was first published in 1950 in the series Literaturnye pamjatniki (Lichačëv 2007). An edition of a different nature was published in 2003: an interlinear collation of the five main manuscripts, prepared by Donald G. Ostrowski together with David J. Birnbaum and Horace G. Lunt (Ostrowski 2003). I have used the online version of this edition, accessible at http://hudce7.harvard.edu/ ostrowski/pvl/. It also contains the readings of certain earlier editions, including Lichačëv's, and a proposed best reading, arrived at through the construction and use of a stemma. The principles for this edition were 'to reduce normalizations to a minimum in order to represent the manuscripts as accurately as possible', which in particular means that distinctions that may have been due to orthographic rules were rendered, but paleographic variation was normalized. Interestingly, regarding the different ways of spelling the phoneme /i/, mentioned above, the editors distinguish four letters: $\boldsymbol{u}, i$, $i$ and $\iota$. Diacritics were not represented, except for the titlo sign, which accompanies abbreviations (Ostrowski 2003: LXXIV-LXXV).

By way of illustration, I will show two screenshots of the online version of this edition, published here with kind permission from Donald G. Ostrowski. In Figure 5, the five first rows represent the five main manuscripts, including the Laurentian Codex, labeled Laur. The three following rows represent different editions, including Lichačëv's edition, labeled Likh. The proposed best reading is labeled $\alpha$.

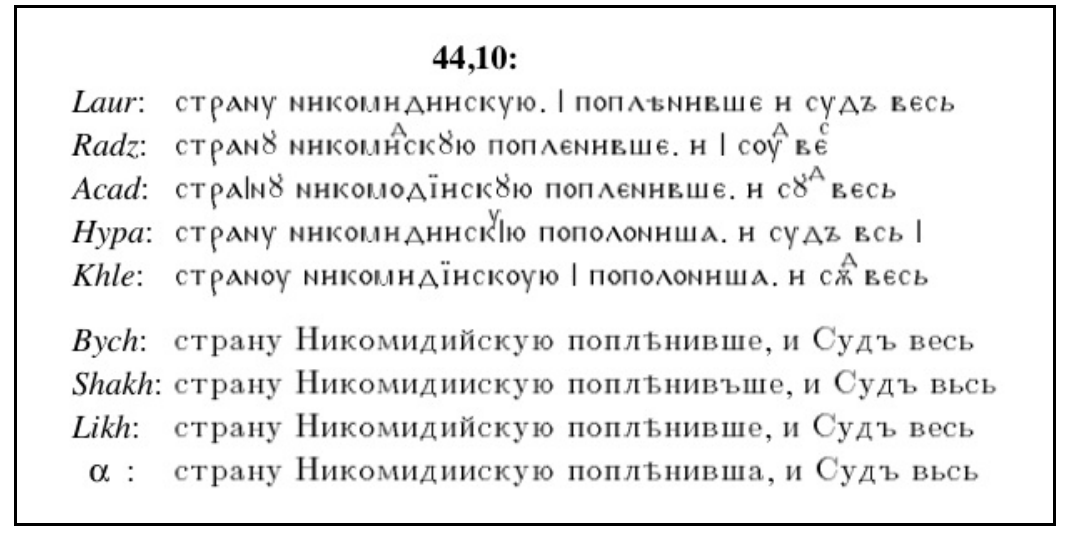

Figure 5. Ostrowski 2003: 256.

In the representations of the five manuscripts in Figure 5, we see that a distinction is made between $y$, oy, $\boldsymbol{b}$ and $x$ in the word Судъ, the second-to-last word of the line (a toponym referring to the Golden Horn in Constantinople).

In Figure 6, the top five and bottom four lines are the same as in Figure 5. The three middle lines represent editions of manuscripts of another early Russian chronicle, the First Novgorod Chronicle, provided for comparison. 


\section{1,18:}

Laur: возва ю ЧрРЬ І н РЕТЕ ЕН ХОџю ТА ПОНТн СОБь

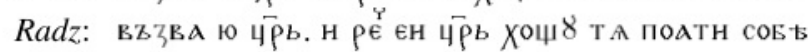

Acad: воzва ю црь. н рете єн ХОџю І та понатн СоБь

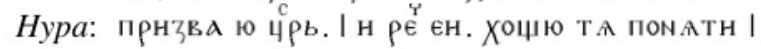

Khle: прнзва юц цръ. І н ретє єн. ХОџоу та поАтн

Coтm: призва ю цесарь и глагола еи хощу тя поняти себь

NAca: призва ю царь и рече еи хощу тя поняти

Tols: призва ю царь и рече еи хощу тя поняти

Bych: возва ю царь, и рече ей: “хощю тя пояти собь

Shakh: призъва ю цьсарь, и рече еи: “хощю тя пояти собь

Likh: возва ю царь, и рече ей: "Хощю тя пояти собь

$\alpha: \quad$ призъва ю цьсарь, и рече еи: “Хощю тя пояти

Figure 6. Ostrowski 2003: 396.

In Figure 6, we see that the abbreviation цірь (the third word of the line) has been expanded differently by different editors (the four bottom lines), either аs царь 'tsar' or as цъсарь/цьсарь 'еmperor'. The former word developed from the latter, and the abbreviation could be expanded in either way. It should be noted that one of the manuscripts has ц.pь, i.e. with a superscript $c$, which would support the reading цъсарь/цьсарь.

We can also see that Lichačëv does not follow his own recommendations of keeping the letter $r q$ in editions of early manuscripts, but instead substitutes it for $я$ in пояти 'to take', the second-to-last word of the line.

\section{Summary and attempt at explanation}

As has been illustrated above, the main dividing line in the attitude towards Latin editions runs between classical and medieval texts, whereas in Slavic tradition, there is not only a chronological division, but also a distinction based on the intended readers of the edition.

Editions of medieval Latin texts may reflect the orthography of the original in a way that editions of classical texts rarely do, but as a rule they do not attempt to show purely graphic variation or evoke the handwriting with the help of the font, which, however, is common in Slavic editions (especially those aimed at linguists).

One explanation for the differences has already been touched upon: an important part of Latin tradition consists of manuscripts that are removed by many centuries from the original versions of the texts, which has made scholars place more emphasis on the text than on the manuscripts themselves. Of course, many Slavic manuscripts are also relatively late copies, but the difference in time is not quite as great, due to the fact that the Cyrillic alphabet was not devised until the $9^{\text {th }}$ century.

The differences in how the languages are learned and used may also play a role. Because of the status Latin had as the language of learning in most of Europe, knowledge of Latin is 
necessary for many scholars of other disciplines, who are not primarily interested in the language itself. Most students who learn OCS or Old Russian also learn from the very beginning to read Church Slavonic script, which is used not only in books aimed at Russian readers, but also in books in English (Nandriş 1965) and German (Leskien 1886). One English-language Russian historical grammar uses a Church Slavonic typeface (there called Palaeocyrillic) for OCS and a modern typeface (called Neocyrillic) for Old Russian examples (Matthews 1960: viii). In this process, it is also necessary to learn the letters that are no longer in use in modern Slavic languages.

In the history of early European printing, the choice of font was a matter of language. In Germany, Latin and German were originally printed using different varieties of Gothic script Rotunda and Bastarda, respectively (Bischoff 1986: 201). In Italy, the handwritten humanist minuscule was popular and firmly associated with the Renaissance, and for this reason the first printers to take up work there, Konrad Sweynheym and Arnold Pannartz, based their type, the first Roman script, on it instead of printing in Gothic type (Mazal 1984: 198). One of the first two printed editions of a classical text, the 1465 edition of Cicero's De oratore by Sweynheym and Pannartz, was also among the first books to be printed in Roman type (Hall 1991: 35-40; Grafton, Most \& Settis 2010: 142), and many more editiones principes of classical authors in Roman type followed (Hall 1991: 15-19). Thus, although Latin had previously been printed in Gothic type, it is noteworthy that the connection between Roman script and editions of classical Latin texts was established from the beginning.

Around 1550, Roman script was used in France and Spain for printing vernacular texts as well. In Germany, it was used for Latin and the Romance languages, as well as for isolated words and quotes in these languages, even when the main text was set in Gothic type (Lexikon des gesamten Buchwesens I: 104-105). The same phenomenon can be seen in early printed books in other non-Romance languages; my own experience includes books in e.g. Swedish and Polish. This confirms the strong connection between the Latin language and Roman script.

In Russia, the civil script was not connected with a classical ideal and the revival of an earlier script, as Roman type was, but was a complete innovation when it was introduced in 1710. Church Slavonic type, on the other hand, was associated with tradition, which made it a possible choice for editions of early texts. Many texts, especially religious ones, but also secular ones such as laws, decrees, occasional poetry and schoolbooks, continued to be printed in Church Slavonic type even after the introduction of the civil script. In the secular realm, where the two scripts competed, Church Slavonic type was used especially in texts that were intended for a wide public. Sometimes the same text could be published in both scripts. This continued throughout the $18^{\text {th }}$ century (Afanas'eva 1979). Church Slavonic script is still used in religious contexts.

The letters found in the classical Latin alphabet are still found in most languages that use the Latin alphabet, whereas many Cyrillic letters have disappeared since that alphabet was first devised. The outdated Cyrillic letters have posed problems to editors of old Slavic texts because of the absence of these letters from typewriters and computer fonts. Nowadays, it is possible to 
add almost any sign to a font, and these growing possibilities raise the question of where to stop. Editors of Slavic texts have to decide how much detail a reader can reasonably want and handle.

There is no simple answer to that question. I am inclined to agree with Lichačëv in that linguists require one kind of edition that will allow them to study the language in detail, while other readers, who are mostly interested in the contents, need another. One argument in favor of some extent of normalization is the increasing desire to digitize texts and make them searchable on computers. This is made easier if orthography is normalized and graphic variation kept to a minimum, although the development of software that can handle a certain amount of orthographic variation lessens the weight of this argument.

On the other hand, in printed editions, especially in those intended for linguists, I believe in distinguishing between letters that had different origins, even when we do not know if the scribes saw them as separate or only as variants. However, variants of a single letter that never developed into separate letters - such as the variants of the letter $\boldsymbol{\theta}$ in Figure 4 - can be assumed to have been decorative, adding visual variation and perhaps facilitating reading, but not carrying any information. This, together with the above-mentioned assumption that such variation is in any event best studied by turning to the manuscripts themselves, prompts me to maintain that such variants do not need to be rendered in editions.

Department of Modern Languages

Uppsala University

Box 636

75126 Uppsala

Sweden

christine.watson@moderna.uu.se

\section{REFERENCES}

Afanas’eva, T. A. 1979. Izdanija kirilličeskoj pečati XVIII veka svetskogo soderžanija. In Problemy istočnikovedčeskogo izučenija rukopisnych i staropečatnych fondov, vol. 1, 183-199. Leningrad: Gosudarstvennaja publičnaja biblioteka.

Bischoff, Bernhard. 1986. Paläographie des römischen Altertums und des abendländischen Mittelalters (Grundlagen der Germanistik 24). $2^{\text {nd }}$ edn. Berlin: Erich Schmidt.

Čerepnin, L. V. 1956. Russkaja paleografija. Moscow: Gosudarstvennoe izdatel’stvo političeskoj literatury.

Gejrot, Claes. 1995. Principer för transkribering/edering av texter inom projektet (Vadstenabrödernas predikan. Meddelanden 2). Uppsala: Institutionen för klassiska språk.

Grafton, Anthony, Glenn W. Most \& Salvatore Settis (eds.). 2010. The classical tradition. Cambridge, MA/London: Belknap Press of Harvard University Press. 
Hall, Edwin. 1991. Sweynheym \& Pannartz and the origins of printing in Italy: German technology and Italian humanism in Renaissance Rome. McMinnville, OR: Bird \& Bull Press for Phillip J. Pirages.

Huygens, R. B. C. 2000. Ars Edendi. A practical introduction to editing medieval Latin texts. Turnhout: Brepols.

Leskien, A. 1886. Handbuch der altbulgarischen (altkirchenslavischen) Sprache: Grammatik. Texte. Glossar, $2^{\text {nd }}$ edn. Weimar: Hermann Böhlau.

Lexikon des gesamten Buchwesens, vol. 1, $2^{\text {nd }}$ edn. 1987. Stuttgart: Anton Hiersemann.

Lichačëv, D. S. 2001. Tekstologija na materiale russkoj literatury X-XVII vekov (Slavjanskaja biblioteka. Bibliotheka Slavica), $3^{\text {rd }}$ edn. St. Petersburg: Aletejja.

Lichačëv, D. S. 2007. Povest'vremennych let. Podgotovka teksta, perevod, stat'i i kommentarii D. S. Lichačëva (Literaturnye pamjatniki), $3^{\text {rd }}$ edn. St. Petersburg: Nauka.

Matthews, W. K. 1960. Russian historical grammar (London East European Series). London: Athlone Press.

Mazal, Otto. 1984. Paläographie und Paläotypie: Zur Geschichte der Schrift im Zeitalter der Inkunabeln (Bibliothek des Buchwesens 8). Stuttgart: Anton Hiersemann.

Nandriş, Grigore. 1965. Handbook of Old Church Slavonic, part I: Old Church Slavonic grammar (London East European Series). London: Athlone Press.

Öberg, Jan. 1992. Det trots allt möjligas konst: Textutgivning i en latinists perspektiv. In Jonas Carlquist (ed.), Föreläsningar i medeltidsfilologi (Meddelanden från Institutionen för nordiska språk vid Stockholms universitet 38), 57-111. Stockholm: Institutionen för nordiska språk.

Ostrowski, Donald G. 2003. The Pověst'vremennykh lèt: An interlinear collation and paradosis. Compiled and edited by Donald G. Ostrowski (Harvard Library of Early Ukrainian Literature. Texts 10: 1-3). Cambridge, MA: Harvard University Press. Available online: http://hudce7.harvard.edu/ ostrowski/pvl/ (Last accessed on 24 April 2013).

Pennington, Anne. 1980. Grigorij Kotošixin. O Rossii v carstvovanie Alekseja Mixajloviča. Edited with a commentary by A. E. Pennington. Oxford: Clarendon Press.

Pravila lingvističeskogo izdanija pamjatnikov drevnerusskoj pis'mennosti. 1961. Moscow: Izdatel'stvo Akademii nauk SSSR.

Šustova, Ju. Ė. 2011. Nazvanija i grafika bukv kirillicy v pečatnych azbukach XVI-XVII vv. In Kirillica ot vozniknovenija do našich dnej, 110-154. St. Petersburg: Aletejja.

Tarrant, R. J. 1995. Classical Latin literature. In D. C. Greetham (ed.), Scholarly editing: A guide to research, 95-148. New York: Modern Language Association of America.

Truber, Primus. 1959. Cirilska tabla za dicu 1561. Ljubljana.

Uspenskij, B. A. \& V. M. Živov. 1983. Vydajuščijsja vklad v izučenie russkogo jazyka XVII veka. Review article on Anne Pennington, Grigorij Kotošixin. O Rossii v carstvovanie Alekseja Mixajloviča, 1980. International Journal of Slavic Linguistics and Poetics 28, 149-180. 
Watson, Christine. 2012. Tradition and translation: Maciej Stryjkowski's Polish chronicle in seventeenth-century Russian manuscripts (Studia Slavica Upsaliensia 46). Uppsala: Acta Universitatis Upsaliensis.

Ziegler, K. 1969. M. Tullius Cicero: De re publica (Bibliotheka scriptorum Graecorum et Romanorum Teubneriana), $7^{\text {th }}$ edn. Leipzig: Teubner. 